\title{
O SOLO DO PARAÍSO
}

\author{
The soil of paradise
}

\author{
Edson Passetti ${ }^{1}$ \\ Gustavo Simões ${ }^{2}$
}

\begin{abstract}
RESUMO
Em "O solo do paraíso" procuramos situar a produção da verdade sobre as Américas do Sul e Central como paraíso terreno dos sonhos sisudos do cristianismo dissolvidos em derrisórias atitudes voltadas para os anarquismos. Vida de andarilhos da liberdade, militantistas que se dispensam dos ativistas contemporâneos e se apartam com ideal estadunidense de democracia que contamina o planeta nesta era ecopolítica.
\end{abstract}

Palavras-Chave: paraíso, anarquismos, militantismo, ativismo, ecopolítica.

\begin{abstract}
In 'The soil of paradise,' we seek to situate the production of truth about Central and South America as an earthly paradise for the severe dreams of Christianity dissolved in derisive attitudes towards anarchism. The life of freedom walkers, militantists who dispense with contemporary activists and depart from an American ideal of democracy, contaminates the planet in this ecopolitical era.
\end{abstract}

Keywords: Paradise; Anarchism; Militantism; Activism; Ecopolitics.

1 Edson Passetti, professor livre-docente do departamento de ciências sociais e programa de estudos pós-graduados em ciências sociais puc-sp. coordena o nu-sol (núcleo de sociabilidade libertária www.nu-sol.org), edita o Observatório Ecopolítica (https://www5.pucsp.br/ecopolitica/observatorio-ecopolitica/ ). E-mail: edson.passetti@uol.com.br

2 Gustavo Simões, doutor em ciências socais e integrante do nu-sol, edita a revista verve, é o cantor e compositor gustavo galo. E-mail: gusfsimoes@gmail.com 
Antes mesmo dos primeiros colonizadores chegarem à América Central eà do Sul, com espanhóis e portugueses, depois seguidos por franceses e holandeses, pelo Atlântico e o Pacífico, espaços habitados por indígenas nus no litoral, sob o sol do Equador e o frio do sul do continente, muito antes mesmo, "desde a Idade Média, bem antes portanto de ser uma nação geograficamente definida, o nome Brasil já designava uma ilha fantasiosa que no imaginário europeu era uma das tantas representações do Paraíso terrestre. Também conhecida como Ínsula Deliciosa, a Ilha Brasil aparecia, nos primeiros mapas, em torno da costa da Irlanda, e foi freneticamente buscada pelos navegadores ingleses do período" (TREVISAN, 2018 [1986]: 44).

O Brasil, a Amazônia, o Pantanal, a Mata Atlântica, os Andes amazônicos, vistos sem fronteiras, são o imenso espaço continental de possível El Dorado, de destruídas Missões, e de Andes secos que se erguem em montanhas e desertos com o mais limpo e claro céu noturno estrelado, onde nem mesmo cadáveres se decompõem e se instalaram avançados telescópios a vasculhar a imensidão sideral; desertos dos pequenos e grandes cantos onde a ditadura Pinochet matou e deu desaparecimento de muita gente, assim como anteriormente a mineração capitalista, pretendendo apagar uma nostalgia da luz (como no filme de Patrício Guzmán, Nostalgia da luz, 2010). Os possíveis sonhos paradisíacos de europeus exóticos, materializados em devastação portuguesa-espanhola, e em degeneração, degradação e destruição sob os toques de clarins europeus e estadunidenses, estão agora sob a atual suposta salvaguarda europeia (quem outrora destruiu, atualmente pretende governar a conservação de um tanto de possível), sob a bênção do cristianismo de sempre, voltado às tradições metafísicas, às pobrezas, ou mais recentemente aos direitos e às novas condutas adequadas, sob o ecumenismo religioso ou racional do governo fundado na cooperação e na competição pela racionalidade neoliberal capitalista, sempre normal, normalizado.

\section{andarilhos: anarquistas e indígenas}

O anarquista José Oiticica, preso em 1925, ao passar pela Ilha das Flores e do Bom Jesus, redigiu uma contundente reflexão, A doutrina anarquista ao alcance de todos, publicada no jornal Ação Direta em 1947 
e depois feita livro. Para Oiticica, "religião é o processo de subjugar o povo fazendo-o crer num ser onipotente, invisível, dono do universo, castigador dos maus, premiador dos bons. Os maus, naturalmente, são os que se desviam das normas ditadas pelos sacerdotes e atribuídas à divindade (...) No ocidente europeu e americano, a religião dominante é a cristã, quer romana, quer protestante, quer ortodoxa (...) Os três ramos dessa Igreja, supramencionados, divergem acesamente, sobretudo o romano e protestante que se excomungam e se odeiam" (OITICICA, 1983: 33). O anarquista, a respeito da criação religiosa do paraíso como efeito da obediência às autoridades e com respeito à propriedade, argumentou: "os sacerdotes romanos, chefiados pelo papa de Roma, têm a seu cargo salvar as almas humanas, separadas do corpo pela morte, dos castigos infligidos eternamente, num lugar de suplícios, o inferno. Para furtar-se a tais torturas, devem os homens, acima de tudo, observar os mandamentos da lei de Deus e os dogmas da Igreja. Esses mandamentos e dogmas encaminham os homens ao respeito à propriedade e à obediência aos superiores, considerados representantes de Deus na terra (...) Se, porém, os trabalhadores se revoltam contra os patrões, os cidadãos contra o governo, ou se a nação declara guerra a outra, por mais injusta que seja, a polícia pode matar e os exércitos se estraçalharem sem pecado" (OITICICA, 1983: 33, grifos do autor). Aqui se encontra presente a instigante leitura de Mikhail Bakunin sobre as três religiões fundantes da sociedade ocidental e, por que não dizer, globalizada, em busca dos respectivos paraísos: o judaísmo, o cristianismo o e o islamismo (BAKUNIN, 2007).

Contemporâneo de Oiticica, outro anarquista, Florentino de Carvalho, reiterou, ao seu modo, as afirmações do autor de Ação Direta e de Bakunin. Vindo ainda criança da Espanha, muito jovem recusou a formação católica. Em uma série de artigos publicados em A Plebe no início dos anos 1930, alertou para a ideia de paraíso católico, produção religiosa de um futuro pacificado e redentor. Assim como outros libertários que viveram no Brasil no início do século XX, afetados pelos escritos de Liev Tolstói (em que repercute um cristianismo de catacumbas) e Piotr Kropotkin, contestou diretamente a linguagem forjada pela Igreja e seus sacerdotes. Defendendo as práticas de liberdade anteriores à instituição do clero, sublinhou: "Os chamados profetas da civilização da Judeia, Isaías, Malaquias etc., já falaram de um reinado de igualdade para os seres humanos, sem que em sua linguagem se fizesse referência - como se pretendeu falsear depois, a um paraíso de ultratumba" (CARVALHO, 2020: 104-105). 
Agitadores contundentes nas primeiras décadas do século XX, Oiticica e Carvalho escreveram incansavelmente em diversos jornais, entre eles, o anticlerical A Lanterna, editado muitos anos por Edgar Leuenroth. Por suas vidas vibrantes, na primeira metade do século XX, ambos foram duramente perseguidos e encarcerados. Oiticica passou temporadas recluso na Ilha das Flores e em Bom Jesus. Florentino de Carvalho foi preso em São Paulo, Santos, Recife e nos navios-prisão Curvello e Avaré. Vários de seus contemporâneos e amigos de combate foram enviados pelo Estado para o campo de concentração da Clevelândia, na Amazônia. A prisão localizada em Oiapoque, no Amapá, criação do presidente Artur Bernardes em 1924, logo após a repressão à chamada Revolução de Julho, ficou conhecida durante muitos anos como "Inferno Verde".

Inspirada na "Ilha do Diabo", prisão mantida pela França na vizinha brasileira, a Guiana, o suposto inferno criado por Arthur Bernardes, Clevelândia, é o resultado do terror de Estado ao anarquismo e do decreto de estado de sítio entre 1924 e 1926. Depois de entupir as cadeias de São Paulo e Rio de Janeiro, o então presidente ordenou o envio de mais de mil homens para a distante Clevelândia, na época um recente núcleo agrícola. Uma parte considerável dos presos rumo ao norte do país, em um trajeto composto de dias de viagem em navios e barcos cárceres, era formada por anarquistas, identificados por autoridades como o maior perigo para a segurança nacional. Situada no Oiapoque, em língua Tupi “oiap-oca", a casa dos Waiãpi, um povo indígena que habita a Amazônia, Clevelândia, o campo de concentração, serviu à tentativa política de destruição do pensamento e práticas de liberdade anarquistas, e consolidou o sequestro militar de região fronteiriça, terra de diversos povos indígenas.

Pela América Central e do Sul, principalmente entre a segunda metade do século XIX e a primeira do século XX, os anarquistas e os povos autóctones foram alvos, respectivamente, do massacre das políticas estatais voltadas para o saneamento político-ideológico dos centros urbanos industrializados e da conquista do oeste.

Contudo, anarquistas e indígenas também se encontraram em seus percursos livres e em suas lutas conjuntas. Em 1860, ao norte da América, nos Estados Unidos, Joseph Déjacque, por exemplo, posicionou-se ao lado dos Pah-Utes e em confronto direto com militares na Califórnia (DÉJACQUE, 2013). No país vizinho, o México, a partir dos anos 1870, depois de décadas de sublevações yaquis e mayas, o encontro de comunards exilados e certos indígenas empolgou parte das resistências afirmadas por Ricardo Flores 
Magón no início do século XX (http://archivomagon.net/inicio/biografia/). Também sobre a dispersão após a Comuna de Paris, Claure Auzias, em artigo sobre a vida de Louise Michel, conta que a anarquista, condenada pelo tribunal militar da França em dezembro de 1871, foi exilada pelas autoridades na Nova Caledônia. No território colonial francês, situado no Oceano Pacífico (cortado pelo Trópico de Capricórnio), durante uma década ela coexistiu com os índios Kanak: "confraternizou com eles, aprendeu sua língua, recolheu seus contos e lendas e lhes ensinou a escrita. Dividiu ao meio sua echarpe vermelha da Comuna e ofereceu-lhes uma das partes (...). Os Kanak curaram o luto melancólico de Louise Michel, devolveram-lhe o gosto pela luta. Continuaram representando, por toda sua vida, a essência dos povos excluídos pelo pensamento único revolucionário" (AUZIAS, 2006: 106).

Entretanto, ainda hoje pouco se sabe sobre o campo de concentração da Clevelândia do Norte (ROMANI, 2003). Por meio de relatos e documentos, sabemos que aproximadamente metade do contingente encerrado ali morreu de fome ou acometido por doenças típicas da floresta. Pedro Catallo (2007), sapateiro libertário, conta que o anarquista Domingos Passos, um dos poucos a conseguir escapar do campo depois de atravessar rios a nado, carregou por anos os efeitos de uma febre palustre. A existência de Passos, bem como a de Eugène Dieudonné (https://www.anarquista.net/eugene-dieudonne/), anarquista francês que compunha o Bando Bonnot (http://www.anarquista. net/jules-bonnot/) no início dos anos 1910, e que escapou da prisão guianense Saint Joseph em uma canoa fabricada com folhas de palmeira, expõem a força das resistências antiestatais, antipolíticas, anticoloniais ao sul do éden americano, essa paisagem imaginária criada e construída há séculos pela Europa. Há certo tempo, não são poucos os jovens libertários que procuram estabelecer relações entre povos nômades indígenas da América do Sul e os anarquismos, principalmente a partir das reflexões instauradoras do antropólogo Pierre Clastres (Passetti, 2020), desde a coletânea $A$ sociedade contra o Estado, publicada inicialmente em 1974.

Quase duas décadas depois das afirmações do avô José no jornal Ação Direta, o artista Hélio Oiticica, em 1967, durante a ditadura civilmilitar, apresentou sua corajosa "Tropicália", composta por materiais como plantas, araras, areia, pedras, a partir de suas vivências pelas "quebradas cariocas", em especial, no Morro da Mangueira. A proposição visava, segundo o artista, derrubar o mito universalista da cultura brasileira calcada na Europa e na América do Norte. "Para a criação de uma verdadeira cultura, característica e forte, expressiva ao menos, essa herança maldita 
europeia e americana terá de ser absorvida, antropofagicamente, pela negra e índia da nossa terra (...) o mito da tropicalidade é muito mais do que araras e bananeiras: é a consciência de um não condicionamento às estruturas estabelecidas, portanto altamente revolucionário (...). Qualquer conformismo, seja intelectual, social, existencial, escapa a sua ideia principal" (OITICICA, 1992: p. 125-126), disparou.

Apesar de escamoteado pela ampla maioria de críticos e historiadores da arte, que pretendem colocar em um escaninho o inclassificável Hélio Oiticica, em variados momentos, ele citou o avô anarquista como uma de suas mais vitais referências. Como observou Beatriz Carneiro, as transformações entre os Oiticica "se realizavam há pelo menos duas gerações. O avô enfrentou na carne padres, polícia, partidos (...). O pai consolidou um estilo de vida libertário na vivência cotidiana. A família afastava-se dos cânones de culpa e dissimulações corriqueiras na educação" (CARNEIRO, 2003: 181).

Cada vez menos interessado em objetos-obra e mais em propostas tidas como ambientais, dois anos depois da sua Tropicália, em 1969, em Londres (na mesma terra onde se imaginava na Idade Média a "Ínsula Deliciosa" chamada Brasil), Hélio Oiticica propôs uma nova experiência, chamada "Éden". Um ano depois de vivenciar o "Paradise Now", obra coletiva do grupo de teatro anarquista The Living Theatre, mais interessado no paraíso como um presente prazeroso e sem a criação do pecado, anticlerical como o avô e Florentino de Carvalho, "Hélio acopla um aspirador e um saco com café dentro para você sentir brutalmente, como se fosse Adão, pela primeira vez, a sensibilidade direta colado com o cheiro, o cheiro desimpregnado da trivialidade cotidiana e impregnando você pela intensidade bruta. No gesto simples de cheirar o café há um traço de pecado porque lembra cafungar cocaína. Hélio desejou erradicar esse traço de pecado" (SALOMÃO, 1996: 65), recordou Waly Salomão. Para o poeta, o ÉDEN do artista é oposto à tradução judaico-cristã, pois, "não é um ÉDEN que precede a queda, o ÉDEN HO é o que redime da queda. Redimir-se da queda não pelo mecanismo culposo da labuta alienada - ganhar o pão suado - mas através de uma atitude erótica não repressiva em relação à realidade" (IDEM).

Com José e Hélio Oiticica, pensar livremente a partir do sul da América é combater diretamente a religião imposta desde o início da construção do Brasil pela Europa. Se José Oiticica foi uma das grandes referências anticlericais anarquistas da primeira metade do século $\mathrm{XX}$, o artista Hélio Oiticica afirmou a sua revolta antieuropeia e antiestadunidense por meio de uma atitude antropofágica singular, radicalizada em meados da 
década de 1960. Amiga próxima do Oiticica mais jovem, outra artista, Lygia Pape, declarava-se "intrinsecamente anarquista" e, também, intensificou a perspectiva da antropofagia. "Lembro que o Manto Tupinambá seria cedido pelo Museu do Homem de Paris, pois aqui todos sumiram ou foram destruídos. Eu prefiro fazer meus mantos (...). Eu prefiro fazer minhas homenagens particulares, construindo meu poema tupinambá (...) a história do chefe Cunhambebe, que usava um manto feito de penas tiradas do pássaro guará, pássaro que conheço, (...) essas coisas têm para mim uma ligação muito grande. Além disso, há a questão da antropofagia, da devoração da cultura do outro. Mantos tupinambás já fiz vários. Um é uma grande nuvem vermelha sobre a cidade (...), quando atravesso a Baía de Guanabara, faço um filme, imagino baleias, botos, os índios, eu fico sonhando, visito meu passado, a história se superpõe" (PAPE, 2003: 89). Da pintura corporal Kadiwéu (DJURÁN, 2015; RIBEIRO, 1980) ao Manto de Lygia Pape, há prazer e liberdade que não cabem no mundo ocidental afeito a ascensões e quedas (iniciadas por Adão e Eva, seguidas, como preferirem, pelo Império Romano, a sempre eterna do capitalismo emblemática nos dramas esquerdistas de Bertolt Brecht, como "Ascensão e queda da cidade de Mahagonny”, “A ascensão de Arturo Ui”, e no III Reich), enfim, a relação anarquistas-indígenas está fora do que comunica religião, razão e temática da esquerda política.

Anarquistas e indígenas, estes seres a se mirar e cruzar, sem confins, sabem cada qual a seu modo que "quem alcançou em alguma medida a liberdade da razão, não pode se sentir mais que um andarilho sobre a Terra - e não um viajante que se dirige a uma meta final: pois esta não existe" (NIETZSCHE, 2000 [1886]: $306\{638\}$ ).

O solo do paraíso não é algo imaculado destinado a ser tocado por alguém especial para torná-lo produtivo, dele extrair riquezas e delícias saborosas, decompor gente em escrava ou em peça para o gabinete real, paisagem em propriedade. O paraíso não é a natureza intocada ou idealizada, tampouco restaurada, é somente um jeito de tocar na terra de modo abençoado: "o sonho do Brasil como paraíso continuou fecundando a fantasia europeia, indo articular-se de maneira radical na teoria do aventureiro e visionário Pedro de Rates Henequim, um lisboeta que viveu no século XVIII e morou por vinte anos em Minas Gerais, garimpando ouro. Autointitulado profeta, após seu regresso a Portugal, Henequim passou a divulgar a ideia de que o Jardim do Éden se situava no Brasil, local onde Deus iniciara a criação, inclusive falando a língua portuguesa. Para Henequim, o fruto proibido não 
era a maçã, e sim a banana, e os rios do Paraíso chamavam-se São Francisco e Amazonas. Dizia também que Adão não passava de um índio brasileiro, fato corroborado por sua pele vermelha inscrita em seu próprio nome, já que a palavra 'adom' significa 'vermelho' em língua hebraica. Henequim foi enforcado e seu corpo queimado pela Inquisição Portuguesa, em 1744, acusado de uma heresia" (TREVISAN, 2018: 44). Que paraíso terreno, não? Ou melhor, o discurso da ordem não admite a aproximação entre as práticas indígenas de tribos com organização hierárquica restrita e os anarquismos. Simplesmente, "no começo nosso planeta era quente, amarelento e tinha cheiro de cerveja podre. O chão era sujo de uma lama fervente e pegajosa" (HERINGER, 2016: 11).

a vida não cabe num ato, decreto, livro sagrado ou profano...

A arrogância humana é enorme e exagerada. Determina as leis da natureza, a vivência com religião entre povos nômades e isolados, a evolução civilizatória, a divina criação do mundo (incluindo a Terra como centro do mundo, a Europa como o centro da Terra, colonizando todos os cantos do planeta, os EUA como centro do globo), a beleza chamada o humano proprietário em aperfeiçoamento (que, com obviedade, mira-se na imagem de Deus), a meta para qual cada um destes seres deve seguir rosado, feliz e responsável. "A população de tizius no Queím gira em torno de meia dúzia de indivíduos, não importa a década. O pássaro mesmo, que inspirou o nome, eu nunca vi. É preto-azul e canta 'ti-ziu, ti-ziu' (ouvi na internet), só isso: 'ti-ziu' a vida inteira. Quando um personagem negro faz sucesso na TV, o número de tizius tende a diminuir, porque as crianças acham outros apelidos: Tião Macalé, Mussum, Pelé, Vera Verão, Obama" (HERINGER, 2016: 90).

Nem tudo renasce, regenera, restaura ou se recompõe. Se esquece, propositalmente, a decomposição dos organismos, apesar de haver estudos sobre os organismos em apodrecimento ao longo do tempo, a tafonomia (taphos, em grego, túmulo), sobre o que desaparece porque é vivo e morre. Como um cavalo que morre tempos depois de degustar e deglutir a grama ou feno em que um gambá urinou, por uma doença conhecida 
como mieloencefalite protozoária equina. O que é vivo morre, porque tem que morrer: uma pessoa, um indivíduo, divíduo, uma espécie. Não cai céu nenhum em cima dos vivos porque outros vivos matam, infectam, separam, exibem suas filantropias. Pode sim um meteoro ou algo gigante vindo do espaço sideral acabar com tudo. Isso pode, com ou sem o(a) melancolia (Lars von Trier, Melancolia, 2011). O resto das produções intencionais de mortes não devem acontecer, nem capitalismo nem socialismo.

Tudo que há de ruim é resultado do erro, falta, queda do humano, como culpa, desacato, atentado ao soberano celestial ou terreno. Doenças, inimizades, loucuras, pandemias, pestes e demais subordinações com as quais o humano aprende a conviver estão naturalmente relacionadas à sequela religiosa ou a uma grosseria ao que é, está ou será superior. Sempre devemos ser devedores dos superiores, ambicionar ser como eles, fazer da nossa existência uma sobrevivência espelhada no governo dos mais fortes, pela força, pela astúcia ou ambas, pela sua beleza. Praticar o contínuo exame de consciência; dispor-nos, mesmo nas descontinuidades, aos condutores de consciência. Sermos menos!

Os descontentes armaram utopias, arquitetaram suas vidas para percorrer certos caminhos certeiros destinados à fantasia que criaram, sonham vivenciar, mas sempre a fortalecer a crença em algo possível, no futuro (jamais lhes passa pela cabeça um no future!, enunciado pelos punks nos anos 1970). Se os gregos justificaram haver a "ilha dos bem-aventurados" para homens especiais, os cristãos legaram o paraíso (e a seu modo, também o islamismo) como o lugar presenteado aos bons e obedientes depois da morte, os líderes comunistas propuseram a Terra como paraíso! O cineasta Elio Petri, em 1971, no filme A classe operário vai ao paraíso, mostrou bem qual era o paraíso reservado a ela. $\mathrm{O}$ grande presente ofertado aos humanos subalternos, pobres, doentes e conformistas; o maior presente aos homens mártires do islamismo; o bom presente ao convalescente que virou doente crônico. Um solo movediço, nada de solo firme, mas o éter (quase ou mais que $o$ aristotélico quinto elemento).

Andre Sant'Anna (2006) segue o garoto que gosta de sanduíche americano servido no prato, acompanhado com refrigerante guaraná, no litoral norte de São Paulo, em busca de dinheiro, fama e mulheres, como jogador de futebol profissional, que acaba negociado com o clube Herta Berlin, na Alemanha, e lá vira terrorista, explode com uma bomba em seu corpo e agoniza num leito de hospital, sonhando com quase uma centena de virgens que Alá lhe ofertará no paraíso depois de sua morte, todas chupando 
as pastilhas verde-açucaradas "Campos de Jordão" para limpar o hálito, para que todas tenham o mesmo hálito, que todas sejam só dele. Finalmente. É um dos paraísos do miserável brasileiro. Tornar-se jogador de futebol de sucesso com carros, mulheres e muita foda, sair do esquecimento e da fome e mostrar que há um paraíso na Terra, sim, para ser atravessado numa Ferrari amarela.

É curioso constatar como o paraíso é a versão do capitalista ou do assalariado bem-sucedido (e do mal também, que ama até mesmo a fétida ou a desinfetada favela "onde nasci"). Neste caso e, por muito menos, homens e mulheres acham que vivem no paraíso, mesmo que zanzando pelo zunir das balas perdidas. Sabem que é preciso amar: a Deus e os deuses/ deusas, a família (hetero ou homoafetiva), a irmandade, esta humanidade de todos (o trabalho, a comida feita, dada, comprada ou doada, os animais, as plantas e a "natureza" e o meio ambiente, a comunidade, o universo, mesmo que surrem suas mulheres, os filhos legítimos ou adotados, os enteados e enteadas ou os/as bolinem...). Melhorar de vida, melhorar na vida, obter mais acesso a variados bens de consumos, restaurantes, viagens e até ecoturismo exitosamente documentados nas redes digitais estampando um self-sorriso. Podem ir longe com os pacotes de viagens ou pelas tecnologias de informação e comunicação; ir até mesmo aos mesmos lugares que a jovem santificável Greta Thunberg e o seu Friday's for Future vão para defender o meio ambiente e produzir jovens lideranças para a defesa contra a degradação do planeta (Observatório Ecopolítica 79).

O paraíso passou a ser natureza definida como meio ambiente preservado/conservado (os termos, à primeira vista, podem parecer contraditórios, mas são complementares por não colocarem riscos ao capitalismo de ontem, hoje e amanhã, à racionalidade neoliberal atual e ao Estado de sempre); preservado/conservado por cada um, por agências e a ser visitado por aqueles que maravilham e se maravilham. Preservado e conservado como constituintes do leque pluralista democrático que sempre inclui. Ser mais radical do que apenas aceitar as medidas de conservação; arregimentar gentes presencialmente ou por redes digitais para cuidados ecológicos e obter a degradação contida, a restauração encaminhada, os acordos do clima cumpridos, nosso dever para que as futuras gerações sobrevivam em um planeta mais humano e preservado, com melhor qualidade de vida. Gente do local e de fora, cidadão da Terra, para além de sua nacionalidade, coisa para cosmopolita. Tudo com muita moderação para não colocar em risco o sistema. Era ecopolítica do incentivo à participação, à formação dos ativistas, a prática de liberdade fecunda à racionalidade 
neoliberal e que orquestra da extrema direita à extrema esquerda política e vice-versa (PASSETTI, 2020; PASSETTI, et al. 2019).

A predominância do ideal estadunidense de democracia conjugado com a dominância da racionalidade neoliberal tem mostrado uma faceta mais que curiosa. Desde que passou para segundo plano o ideal revolucionário de matriz francesa que dominou os séculos XIX e XX, a clássica distinção entre as forças parlamentares em direita e esquerda virou uma miscelânea. Para os propósitos da racionalidade neoliberal não há distinção nítida entre direita e esquerda, assim como centro, e extremas direita e esquerda. O ideal estadunidense oscila entre democratas e republicanos, e depois da II Guerra Mundial isto é cada vez mais nítido, agrupando em seus respectivos interiores esquerda e extrema-esquerda e direita e extrema-direita. Recomenda-se moderação das condutas de seguidores de ambos. Portanto, à direita e à esquerda. Enfatiza-se a defesa da democracia sem radicalismos e tendendo ao centro político-parlamentar para que ocorra fortalecimento dos partidos políticos e das instituições políticas, e ongs, fundações e institutos. Tudo deverá estar contido no leque pluralista democrático-republicano que ilumina o que é direita e esquerda, situa os defensores da democracia liberal, do nacionalismo, das condutas retrógradas, dos reacionarismos, das defesas dos portadores de direitos de minorias, de mais ou menos intervenção do Estado, mas sem deixar de perder a ênfase em educação e saúde. E não "tolerar" nada de contestações fora deste ramerrão.

A Terra não é, nem nunca foi o/um paraíso, mas recomendase que devemos evitar que ela se transforme no inferno. Hoje em dia, mostrando como somos resilientes! Na Terra devemos preservar certos espaços, lugares com natureza paradisíaca com os indígenas incluídos e os isolados, conservar os nativos e os ribeirinhos, estar ao lado e junto (os mais atrevidos aconselham juntos e misturados) com os ecologistas, as empresas de loteamentos seletivos, de exploração de minérios... todos certificados. O civilizado capitalista, defensor da sustentabilidade, da economia verde e da azul, está irmanado aos assalariados e populações locais aninhados em variadas instituições respeitáveis, dispostas até em negociar com os capitalistas selvagens, juízes e políticos, para conservar o que já conseguiram pela sua condição de portadores de direitos inacabados; para redimensionar como e o que comer, incluindo os indígenas em suas terras demarcadas, os quilombolas; para andar todos juntos de cabeça erguida, compondo uma nova política capaz de articular macropolítica e micropolíticas em favor da vida. Parece até que, propositalmente, esqueceram não haver relações de 
trabalho no capitalismo que não sejam precarizadas, e que o investimento no vivo, nesta sociedade-Estado, é sempre no produtivo. O capitalismo e seu Estado de bem ou mal-estar social deixa morrer, e precisa matar (às vezes, explicitamente, como no nazismo, ou mais recentemente, sob a chamada pandemia pelo novo coronavírus, o SARS-CoV-2, primeiro entre os médicos europeus nos hospitais durante o atendimento a infectados e com Covid-19, decidindo quem deveria viver, quem deveria morrer por não haver equipamento necessário ao atendimento). "Só uma espécie cansada inventa o carro-forte, o telemarketing e a plástica no nariz. É tarde demais para morrer com elegância!" (HERINGER, 2016: 112).

A Terra pode não ser e nunca terá sido um paraíso (girando em $A$ via Láctea buñuelesca, em 1969, enquanto os peregrinos seguem linhas retas em direção a Santiago de Compostela), e nem será. As religiões nos ensinaram que nossa casa/nosso lar, pode/deve ser o paraíso (palavra do pastor, palavra do Senhor). A psicanálise instrui a adaptar-nos, a psiquiatria a ajustar-nos, a medicina a termos normalizações na saúde e a sermos normais com o reforço da pedagogia. A história nos forma/informa para que devamos punir e recebamos punições e recompensas (estas também se humanizam ao longo da civilização) para o nosso bem, para a nossa segurança e a de todos. As dicotomias apenas reiteram a complementaridade na suposta contradição. Elogio da moral (NIETZSCHE, 2009).

Por molestar o dono do paraíso o casal de lá foi expulso, recebeu seu castigo e dele adveio o fratricídio, o incesto, a traição, a culpa exponencial. Paraíso, ao seu modo, para quem o merece como proprietário (com seus ajudantes, servos, empregados, escravos), com o bajulador sempre ao lado de quem manda; para o simplório conformista no pequeno cômodo de uma habitação coletiva a ser catalogada como suja, pervertida, empesteada, degenerada e degradada. Por ter, ostentar, ou por humildade, cada um carrega sua versão de paraíso. Mas não há paraíso para quem caminha. $\mathrm{O}$ andarilho não se aproxima dos peregrinos, nem a eles se assemelha. Indígenas nômades, isolados e andarilhos não sabem ou não querem mais saber de paraíso. Vive-se a vida à distância dos bem-intencionados e dos zeladores da ordem: duas faces conservadoras, duas caras moderadas de sentinelas, dois rostos disformes na dor e nos desesperos repetitivos captados pelo pintor Francis Bacon. Duas faces do mesmo rosto que não suporta a alegria e as experimentações do artista da existência Hélio Oiticica com sua arquitetura móvel da revolta (PASSETTI, 2008; PASSETTI E SIMÕES, 2018); que não viram ou notaram a beleza da arte de existir no futebol inventado por Pelé. 
"Não tem leis depois da passarela da avenida Brasil, o portal dos subúrbios. Nem corrupção. O homem puro é aquilo mesmo, um bicho esperto o suficiente para inventar a faca e tirar dela a conclusão mais óbvia: o assassinato. Corruptos são os que escreveram os códigos, porque inventaram o crime. Daí em diante, foi aquela coisa de sempre: cadastros, arquivamentos, carimbagens, homologações, prédios de escritórios, planos de previdências, manuais de boa conduta no trabalho, Kafka, engarrafamentos na avenida Rio Branco, departamento de recursos humanos. Inventaram todo tipo de castração para frear nossas fomes de carniça. Hoje, um urubu é mais homem que o homem - cidadão, funcionário, eunuco" (HERINGER, 2016, p. 29).

Essa reflexão em torno das "invenções" trazidas intensamente pelo jovem escritor, talvez suicida, Heringer, seria ainda mais cruel (atitude antissuicida) se tratadas como "criações": Deus cria, o Homem cria, a Espécie cria, o Autor-Artista cria, o trabalho intelectual CRIA... As criações são resultantes dos efeitos reais na vida de qualquer um para sonhar em fazer deste solo um paraíso: estar conforme às leis, normas, condutas, esculturas fixas ou móveis que preservam as fronteiras dos espaços onde se encontram (como as monitorias em exposições de artistas contemporâneos que impedem que se toque o que foi feito para ser manuseado, ou que se enclausure uma obra no cubo branco dos museus); transgressões conhecidas e toleradas para que reformas se ampliem; espaços delimitados mesmo que em deslocamentos, para que não sobressaia o viajante ou o andarilho e consolide o que constitui o migrante e o turista da existência, os assujeitados, os obedientes e pretendentes à felicidade, simplesmente, os críticos acomodando o melhor no momento ou os ressentidos resmungando.

As invenções são diferentes. Trazem desafios, ineditismos, surpresas e experimentações que podem dar ou não em real, mas que o contêm e o tranformam. As invenções são próprias das heterotopias, em especial das libertárias, para acontecerem neste exato momento, sem que transpirem idealizações temporárias em um espaço, como realização constante de práticas de liberdade e de redução da presença das autoridades hierarquizadas e hierarquizadoras. Em viagens de barco no século XIX, heterotópicos foram a socialista Flora Tristan e, posteriormente, seu neto, o artista Paul Gauguin. Flora, vivendo sua existência no momento das lutas revolucionárias e Gauguin, ao retirar-se da modorrenta vida burguesa na Europa (PASSETTI, 2004) com destino ao Taiti. Heterotopias libertárias não são democráticas, obviamente porque nenhuma heterotopia pretende-se universal, condutora de condutas: estão voltadas para atiçar atitudes. 


\section{o prazer não é sinônimo de paraíso}

"Pierre Moreau, viajante francês que esteve no Brasil a partir de 1645 , relatava que, durante o curto período da colonização holandesa em Pernambuco, 'todos levavam vida lasciva e escandalosa; judeus, cristãos, portugueses, holandeses, ingleses, franceses, alemães, negros, brasilianos, tapuias, mulatos, mamelucos e crioulos coabitavam promiscuamente'. No século XVII, tal fato foi confirmado pelo cronista português Simão de Vasconcelos, para quem os colonos em nada diferiam dos índios, 'porque sendo cristãos viviam a modo dos gentios'. Nesse contexto devasso, operavase uma metamorfose moral: suspendia-se a culpa. Em sua famosa carta sobre a descoberta do Brasil, o escrivão Pero Vaz de Caminha comentava que as mulheres índias andavam com 'suas vergonhas tão altas e tão cerradinhas e tão limpas das cabeleiras que, de as muito bem olharmos, não tínhamos nenhuma vergonha'. No século XVII, a partir de suas vivências no Brasil, o historiador Caspar van Baerle, também conhecido como Gaspar Barléu, universalizou uma curiosa observação, que se tornaria paradigmática: ultra equinoxialem non peccari - 'para além do equador não há pecador'" (TREVISAN, 2018: 67).

Albert Eckhout, pintor holandês, no século XVII, acompanhando a ocupação holandesa no nordeste do Brasil, realizou várias pinturas como botânico, compôs naturezas-mortas, retratou pretos e mestiços, e bichos que viviam por aqui, como também indicou em sua obra pictórica a distinção dos tupis (indígenas que pareciam dispostos à aproximação e convivência de forma domesticada) dos tapuias (que confirmariam as teses exóticas que circulavam pela Europa a respeito da antropofagia, canibalismo, de gente perigosa. E eram mesmo.) A arrogância branca europeia, não só a de espanhóis e portugueses, via as populações locais como parte de uma exuberância à qual eles não só tinham acesso como o direito de governar seus corpos e almas. Não eram humanos que viviam impérios ou culturas similares às que encontraram na Ásia. Passaram a tomar as populações nativas como escravas e, quando este uso, rapidamente, mostrou-se improdutivo, passaram a comercializar corpos escravos com culturas hierarquizadas africanas, por meio das chefias, ou simplesmente, pelo sequestro. Na América espanhola, ao se chocarem com outras culturas hierarquizadas, a questão era a de vencer a guerra, tomar o ouro e a prata, fazer escravos, estabelecer seus monumentos sobre os dos incas, maias ou astecas. 
As culturas identificadas como mais simples ou pouco hierarquizadas ainda não eram alvo de sequestro de bens, esculturas e edificações para acervo de museus europeus. Mas a prática de fazer certos escravos em sujeitos livres para domesticarem seus assemelhados ganhou expansão, notoriedade e efeito de assujeitamento, acostumando-os a serem as vítimas históricas de ontem e de hoje. Estes primeiros colonizadores foram ardilosos ao criarem o controle dos de baixo pelos de baixo, por bondade cristã ou por estratégia de mando e obediência. Construíram, com a adesão dos de baixo, um enraizamento que se hoje permanece menos sanguinário é, todavia, mais atroz, fazendo com que os herdeiros desta condição escravocrata, depois de juridicamente livres, passem a aceitar cada vez mais direitos compensatórios do mesmo Estado branco que quase os dizimou e que agora produz a gestão calculista de suas vidas.

Durante a colônia e o Império, irromperam resistências como os zungus e os quilombos afirmados por mulheres e homens que se liberaram da escravidão. Mais tarde, ao longo do império, eclodiram revoltas negras, como a dos malês e, na ultrapassagem do século XIX e início do XX, episódios como o Dragão do Mar e a Revolta da Vacina levada adiante por João Candido. Os dois últimos acontecimentos foram registrados por Aldir Blanc e João Bosco em "Mestre Sala dos Mares", em 1974, título dado após a censura na ditadura civil-militar vetar os títulos anteriores: "Almirante Negro" e "Navegante Negro". Fica a pergunta: insurgências contemporâneas haverão de empolgar a segunda década do novo milênio? O fato é que hoje não há garantia às terras demarcadas de indígenas ou quilombolas para seus herdeiros comprovados pelo regime da política das leis, simplesmente porque se trata de uma gestão do Estado sobre a terra pública numa economia capitalista. Tudo depende e dependerá das boas intenções dos governantes. E como diz o ditado cristão: de boas intenções o inferno está cheio!

Um ano antes do lançamento de "Mestre Sala dos Mares" na voz de Elis Regina, e três séculos depois de Eckhout e de Gaspar Barléu, veio a chamada geração anos 1960-1970, a geração poético-musical brasileira cantando não haver pecado abaixo do Equador com suas verdades tropicais. E por isso tudo e sem isso tudo, há o sexo, "o que não tem governo e nunca terá" ( $O$ que será? , canção de Chico Buarque de Holanda e Milton Nascimento, 1976). Alguns dos versos de Chico Buarque de Holanda em "Não existe pecado do lado de baixo do Equador" (em Chico canta, LP, 1973), canção composta para a peça "Calabar", foram também censurados pela ditadura civil-militar em 1973, ano em que o governo de Garrastazu 
Médici ampliou ainda mais a tortura e a execução de mulheres e homens resistentes às violências do Estado.

Mesmo com a censura, 1973 foi o ano em que os estranhos e sensuais Secos e Molhados circulavam país adentro. Cinco anos depois, em 1978, Ney Matogrosso, agora em carreira solo, lançou a versão mais escandalosa da canção. Na mesma época, entre jovens, estudantes e anarquistas, rodava o debochado jornal $O$ Inimigo do Rei. O periódico que irrompeu em Salvador não somente atualizava os combates anticlericais dos anarquistas do início do século como os associava às afirmações de 68, sobretudo, as ligadas à intensificação do prazer (SIMÕES, 2007). "Trabalhadores de todo o mundo, façamos uma grande suruba" ou "Quem não trepa se Freud" (BAQUEIRO; NUNES, s/d) eram algumas das reportagens estampadas no jornal, com esculhambações explícitas não somente à ditadura, mas também ao marxismo e à psicanálise. Os jovens integrantes e editores de $O$ Inimigo do Rei, ao lado do já experiente Roberto Freire, com seu "Paraíso Agora" (ensaio publicado também em 1978, em viva eu viva tu viva o rabo do tatu) mexiam, Ney Matogrosso mexia, também, com os costumes sagrados, à direita e à esquerda, criados pela política. Era um tal de mexer os quadris!.

Com os anarquistas e a interpretação radical de Ney Matogrosso, expõe-se com nitidez que em corpos e espaços onde não há pecado, isto é, onde não há a ideia de paraíso e castigo criadas pela igreja e os segmentos superiores destas culturas hierarquizadas, abunda o prazer. Isso não é reduzir os combates libertários ao refúgio hedonista, mas mostrar que para existências corajosas não há luta dissociada de prazer. Décadas antes das liberações dos anos 1960 e 1970, nos últimos anos do século XIX, mais precisamente na Colônia Cecília, mulheres e homens libertários escandalizaram a sociedade brasileira ao experimentaram o prazer tanto no amor como no cultivo autogestionário do estreito pedaço de terra situado no Paraná, assim como se escandalizaram ao se verem pegos por uma mesquinharia dos soberanos, o ciúme. Ninguém é inocente! Apenas uns são mais corajosos que outros para inventarem liberdades e com elas lidar.

"Mas também fiquei pensando que, apesar de tudo, apesar de nossa fragilidade e ignorância, temos uma incrível vantagem sobre as estrelas - o tempo trabalha para nós, nos dando uma enorme possibilidade de transformar o mundo sofredor em um mundo feliz e tranquilo. As estrelas é que estão presas em seu poder e, essencialmente, não conseguem nos ajudar. Criam apenas redes, tecem nos teares cósmicos urdiduras que nós mesmos precisamos preencher com nosso próprio fio. E pensei, então, numa 
hipótese interessante: talvez as estrelas nos vejam da mesma forma como nós enxergamos nossos cães - nossa consciência supera a deles. Em certos momentos, sabemos o que é melhor para nossos bichos de estimação: usamos uma guia para passear com eles e para que não se percam, os esterelizamos para que não se reproduzam despropositadamente e os levamos ao veterinário para tratá-los. No entanto, eles não entendem como, por que ou para quê. Mas acabam se submetendo. Então, talvez, nós também deveríamos nos submeter às influências dos astros, mas despertando, ao mesmo tempo, nossa sensibilidade humana" (TOKARCZUK, 2019: 196).

Em lutas infindáveis anticlericais e antipolíticas, desde a colônia, passando pela Independência e pela Proclamação da República, por ditaduras e democracias, o paraíso, a sua ascensão ou queda, não traz questões importantes, simplesmente por reiterar a cultura do castigo. O paraíso é mais uma criação; no caso, uma criação do próprio "criador", a obra do dr. Frankenstein, mesmo com a sua sensibilidade humana estimulada, é o ser condenado a não dar certo, por ser a aberração científica.

Não há dúvida de que vivemos em um terrível momento de ampliação de violências. Contudo, é sempre possível resistir abolindo as práticas consoladoras e vivendo o prazer, essa invenção incontrolável, por mais de um. Não há prazer no paraíso; o reconhecimento deste prazer no sexo e no erotismo foi a sua condenação a priori, a vivência para a mortificação pelo pecado, a transgressão conhecida favorável à reforma da norma e à lei, consolidação do dogma. Sonhar com o paraíso terreno nada mais é ou será que obedecer aos efeitos de poder dos que comandam. Prazer e paraíso são existências excludentes para indígenas e libertários. Para ambos, andarilhos, indígenas e anarquistas, importam as atitudes e a existência evitam o aparecimento da punição.

\section{Bibliografia citada}

AUZIAS, Claire. "Louise Michel". In verve. Tradução de Dorothea Voegeli Passetti. São Paulo: Nu-Sol, vol. 10, 2006, pp. 101-108. Disponível em: http://www.nu-sol.org/wp-content/uploads/2018/02/Verve10.pdf 
BAQUEIRO, Carlos e NUNES, Eliane. O Inimigo do Rei: imprimindo utopias anarquistas. Rio de Janeiro: Achiamé, s/d.

BAKUNIN, Mikhail, “O princípio do Estado". In verve. São Paulo: Nu-Sol, v. 11, 2007, pp.50-77. http://www.nu-sol.org/verve/verveview1.php?id=11

CARNEIRO, Beatriz. Relâmpagos com claror: Lygia Clark e Hélio Oiticica, vida como obra de arte. São Paulo: FAPESP/ Imaginário, 2004.

CARVALHO, Florentino. “Anarquismo e sindicalismo, $1^{\text {a }}$. Parte". In verve. São Paulo, Nu-Sol, vol. 38, 2020, pp. 104-141. Disponível em: https://www. nu-sol.org/wp-content/uploads/2020/11/verve38.pdf

DURÁN, Maria Raquel da Cruz. "Leituras antropológicas sobre a arte Kadiwéu". Cadernos de Campo n. 24. São Paulo: USP, 2015, pp. 43-70. Disponível em: https://edisciplinas.usp.br/pluginfile.php/3268089/mod resource/content/1/Caduveo.pdf

DÉJACQUE, Joseph. “Joseph Déjacque, Le Libertaire, jornal publicado nos Estados Unidos entre 18587-1861”. In Revista Ecopolítica n.7, São Paulo: PUC-SP, 2013. Disponível em:

HERINGER, Victor. $O$ amor dos homens avulsos. São Paulo: Companhia das Letras, 2016.

MATAR, Denise. Lygia Pape: intrinsicamente anarquista. Rio de Janeiro: Relume Dumará, 2003.

NIETZSCHE, Friedrich. Humano, demasiado humano. Um livro para espíritos livres. Tradução de Paulo César de Souza. São Paulo: Companhia das Letras, 2000.

Genealogia da moral. Tradução de Paulo César de Souza. São Paulo: Companhia das Letras, 2009.

OBSERVATÓRIO ECOPOLÍTICA. São Paulo- Nu-Sol/PUC-SP, n. 79, outubro de 2020. Disponível em : https://www5.pucsp.br/ecopolitica/ observatorio-ecopolitica/n79.html

OITICICA, Hélio. Hélio Oiticica. Catálogo da exposição curada por Guy Brett, Catherine David, Chris Dercon, Luciano Figueiredo, Lygia Pape. Galerie Nationale du Jeu de Paume (Paris), Projeto Helio Oiticica (Rio de Janeiro), Witte de With (Roterdam), 1992. 
OITICICA. José. A doutrina anarquista ao alcance de todos. São Paulo: Econômica, 1983.

PAPE, Lygia. Lygia Pape: Intrinsecamente anarquista. Rio de Janeiro, Relume Dumará, 2003.

PASSETTI, Dorothea. "Pierre Clastres e a antropologia libertária). In Oddone, Bruno G \& Pose, Gustavo M. (eds) Aportes al pensamiento anarquista y a la filosofia contemporánea. Montevidéu: Parrhesía, 2020, pp. 137-151.

PASSETTI, Edson. "Ativismo e militantismo anarquista". In verve. São Paulo: Nu-Sol, vol. 38, 2020, pp. 168-201. Disponível em: https://www.nusol.org/wp-content/uploads/2020/11/verve38.pdf

"A arquitetura da revolta". In Margareth Rago e Silvio Gallo (orgs) Michel Foucault e as insurreições. É inútil revoltar-se?. São Paulo, Intermeios/Fapesp, 2016, pp. 63-71.

"Heterotopias libertárias". In verve. São Paulo: Nu-Sol, vol. 2, 2002, pp. 141-173. Disponível em: http://www.nu-sol.org/wp-content/ uploads/2017/11/verve2.pdf

PASSETTI, E. et. ali. Ecopolítica, São Paulo: Hedrta, 2019.

PASSETTI, Edson e SIMÕES, Gustavo. "68 e os andarilhos". In Direito e práxis. Rio de Janeiro, UERJ, v. 9 n. 2, 2018, pp. 998-1015. Disponível em: $\quad$ https://www.e-publicacoes.uerj.br/index.php/revistaceaju/article/ view/33902

RIBEIRO, Darcy. Kadiwéu. Ensaios etnológicos sobre o saber, o azar e a beleza. Petrópolis: Vozes 1980.

ROMANI, Carlo. "Clevelândia do norte - aqui começa o Brasil!". In verve. São Paulo: Nu-Sol, vol. 3, 2003, pp. 314-320. Disponível em: http://www. nu-sol.org/wp-content/uploads/2017/11/verve3.pdf

SALOMÃO, Wally. Hélio Oiticica. Rio de Janeiro, Relume Dumará, 1996.

SANT'ANNA, André. O paraíso é bem bacana. São Paulo: Companhia das Letras, 2006.

SIMÕES, Gustavo. "Para uma militância divertida: 'o inimigo do rei!, um jornal anarquista". In verve. São Paulo: Nu-Sol, vol. 11, 2007, pp. 168181. Disponível em: http://www.nu-sol.org/wp-content/uploads/2018/02/ Verve11.pdf 
TREVISAN, José S.. Devassos no paraíso: a homossexualidade no Brasil, da colônia a atualidade [1986]. São Paulo: Objetiva, 2018.

TOKARCZUK, Olga. Sobre os ossos dos mortos. Tradução de Olga Baginska-Shinzato. São Paulo: Todavia, 2019.

RECEBIDO EM: 03/03/2021 APROVADO EM: 05/04/2021 